\title{
THE INTERDISCIPLINARY USE OF BLOGS AND ONLINE COMMUNITIES IN TEACHER EDUCATION
}

\begin{abstract}
Online learning is developing rapidly in higher education. As a result, in the Initial Teacher Education Division at The University of Northampton, UK, academics have experimented with methods to embed blogs and online communities into courses to enhance learning for staff and students. This article critically analyses the approach used to examine media rich multimodal content that was shared through these tools. The article models how blogs and communities have enhanced interdisciplinary subject teaching, staff development and student engagement. This is achieved by sharing case studies from our courses which model the strengths and limitations of practices adopted. Focused discussion demonstrates how reflexivity, communities of practice and experimentation with technological teaching strategies fuel the learning that occurred.
\end{abstract}

\section{The Research Context}

In the Initial Teacher Education (ITE) division at the University of Northampton academics embed digital tools in their courses to enhance learning by engaging students, modelling practice and promoting reflection. Experimentation with blogs and online communities for teaching, learning and assessment at the University of Northampton began when Helen Caldwell, a senior lecturer in Computing education, replaced assessed e-portfolios with the use of online blogfolios in a Primary computing module. She then went on to explore the use of blogs and Google+ communities, both singly and in combination in her modules. Rebecca Heaton, a senior lecturer in Art and Design education, also explored these tools from a creative perspective in her subject. When collaborating, it became apparent a team of individuals across the ITE division were interested in embedding innovative technological learning strategies in their courses and so a core group was created to investigate their use within the division. Correlations between the approaches adopted, with a specific focus on blogs and communities, and their limitations and successes to enhance student and staff learning are shared in this article.

\section{Blogs and Communities To Enhance Learning}

Blogging provides participants with an opportunity to respond to their digital world (Collins and Ogier, 2012), it allows them to build content to share socially (Deng and Yuen, 2013; Farmer, 2006) and enables learning development through engagement with each other's work (Churchill, 2009). It has been shown that blogs can enhance learning in higher education (Williams and Jacobs, 2004; Wheeler, 2010) and our academics were keen to explore their use in the field of teacher education. Blogs have also been shown to build learning communities (Yang, 2009), promote active collaboration (Ruepert and Dalgarno, 2011) and increase learning ownership (Farmer, Yeu and Brooks, 2007). Within initial 
teacher education blogs can function as reflective devices for students (Deng and Yuen, 2011), and we also wanted to explore the impact on our trainee and inservice teachers' classroom practice. This paper captures through five case studies how blogs and communities have been used in our setting. It extends Deng and Yuen's (2011) research to consider how multimodal blogs and communities combined with face to face learning events can promote collective learning and reflexivity, and how they can develop teachers' confidence and skills in using technology in their practice.

We have conducted a thematic analysis of five case studies in the teacher education division, which used blogs and communities singularly and in combination to enhance learning. The posted content in these spaces consisted of a range of media-rich digital artefacts and resources, along with related commentary and discussion, and so a theoretical framework was required that took account of this (see tables 1 and 2). We were interested in how multimodal content might be analysed to acknowledge the visual culture in which we all teach and learn (Heaton, 2014). Our model is developmental; we know that multiple approaches exist to analyse multimodal content (Banks, 2007; Pink 2012), but we focus specifically on how the multimodal content shared in our blogs and communities demonstrates three themes: the process of reflexivity; the creation of communities of practice and the adoption of technologic tools and strategies.

Table 1

An Example Framework to Analyse Multimodal Blog Content

\begin{tabular}{|c|c|c|c|c|c|c|}
\hline \multirow{3}{*}{$\begin{array}{l}\begin{array}{l}\text { Coding } \\
\text { Phases }\end{array} \\
\\
\text { Phase 1: } \\
\text { Theoretical } \\
\text { Coding }\end{array}$} & \multicolumn{6}{|c|}{ Coding themes identified } \\
\hline & \multicolumn{2}{|c|}{ Reflexivity } & \multicolumn{2}{|c|}{ Communities of Practice } & \multicolumn{2}{|c|}{ Technologic Innovation } \\
\hline & $\begin{array}{l}\text { Reflective } \\
\text { learning } \\
\text { (Schon, 1983) }\end{array}$ & $\begin{array}{l}\text { Self-directed } \\
\text { learning } \\
\text { (Farmer, } \\
\text { Yeu and } \\
\text { Brooks, } \\
\text { 2007) }\end{array}$ & $\begin{array}{l}\text { Learning } \\
\text { communities } \\
\text { (Yang, 2009) }\end{array}$ & $\begin{array}{l}\text { Socially } \\
\text { shared } \\
\text { content } \\
\text { (Deng and } \\
\text { Yuen, } \\
\text { 2013) }\end{array}$ & $\begin{array}{l}\text { Innovative use } \\
\text { of technology } \\
\text { (Sharples et al. } \\
\text { 2014) }\end{array}$ & \\
\hline $\begin{array}{l}\text { Evidence on } \\
\text { blog }\end{array}$ & $\begin{array}{l}\text { Updates of } \\
\text { information } \\
\text { Transfer of } \\
\text { learning to a } \\
\text { new setting or } \\
\text { scenario }\end{array}$ & $\begin{array}{l}\begin{array}{l}\text { Application } \\
\text { of LOC } \\
\text { principles to } \\
\text { teaching }\end{array} \\
\text { Relating } \\
\text { practice to } \\
\text { theory }\end{array}$ & $\begin{array}{l}\begin{array}{l}\text { Students } \\
\text { reviewing } \\
\text { information }\end{array} \\
\text { Delegating } \\
\text { roles within a } \\
\text { group } \\
\text { Working in } \\
\text { partnership } \\
\text { with } \\
\text { museums }\end{array}$ & $\begin{array}{l}\text { Creation of } \\
\text { resources/ } \\
\text { lesson plans } \\
\text { for other } \\
\text { students } \\
\text { Presentation } \\
\text { software } \\
\text { used }\end{array}$ & $\begin{array}{l}\text { Use of external e- } \\
\text { tools e.g. } \\
\text { thinglink, QR } \\
\text { codes } \\
\text { Uploading and } \\
\text { manipulating own } \\
\text { digital content }\end{array}$ & \\
\hline
\end{tabular}




\begin{tabular}{|c|c|c|c|c|c|c|}
\hline $\begin{array}{l}\text { Phase 2: } \\
\text { Blog content } \\
\text { compared } \\
\text { with the } \\
\text { themes of the } \\
\text { questionnaire } \\
\text { findings }\end{array}$ & $\begin{array}{l}\text { 1.Articulating } \\
\text { understanding } \\
\text { of the } \\
\text { foundation } \\
\text { subjects }\end{array}$ & $\begin{array}{l}2 . \\
\text { Articulating } \\
\text { the value of } \\
\text { LOC } \\
\text { principles }\end{array}$ & $\begin{array}{l}\text { 3.Sharing } \\
\text { beliefs }\end{array}$ & $\begin{array}{l}\text { 4. Sharing } \\
\text { confidence } \\
\text { to develop } \\
\text { children's } \\
\text { skills }\end{array}$ & $\begin{array}{l}\text { 5. Discussion of } \\
\text { progress } \\
\text { towards the blog } \\
\text { assignment and } \\
\text { awareness of } \\
\text { digital literacy }\end{array}$ & $\begin{array}{l}\text { 6. Shared } \\
\text { different } \\
\text { learning } \\
\text { strategies }\end{array}$ \\
\hline $\begin{array}{l}\text { Questionnaire } \\
\text { findings }\end{array}$ & $\begin{array}{l}\text { Confidence } \\
\text { increase }\end{array}$ & $\begin{array}{l}\text { Increased, } \\
\text { less guidance } \\
\text { now required }\end{array}$ & $\begin{array}{l}\text { Foundation } \\
\text { subjects } \\
\text { should be } \\
\text { taught } \\
\text { separately } \\
\text { and together }\end{array}$ & $\begin{array}{l}\text { Increase in } \\
\text { all subject } \\
\text { areas }\end{array}$ & $\begin{array}{l}\text { Student } \\
\text { acknowledgement } \\
\text { of the blog } \\
\text { impacting } \\
\text { learning has } \\
\text { decreased }\end{array}$ & $\begin{array}{l}\text { Confidence } \\
\text { to use these } \\
\text { has increased }\end{array}$ \\
\hline $\begin{array}{l}\text { Evidence on } \\
\text { the blog that } \\
\text { correlated } \\
\text { with the } \\
\text { theme. }\end{array}$ & $\begin{array}{l}\begin{array}{l}\text { Updates of } \\
\text { subject } \\
\text { knowledge }\end{array} \\
\text { Adapting their } \\
\text { own teaching } \\
\text { Learning } \\
\text { transfer }\end{array}$ & $\begin{array}{l}\text { Reiterated } \\
\text { throughout } \\
\text { all content: } \\
\text { narrative, } \\
\text { visuals, } \\
\text { multimodal } \\
\text { content }\end{array}$ & $\begin{array}{l}\text { Narration in } \\
\text { posts } \\
\text { Imagery } \\
\text { selected }\end{array}$ & $\begin{array}{l}\begin{array}{l}\text { Maps of } \\
\text { skill } \\
\text { progression }\end{array} \\
\text { Application } \\
\text { of } \\
\text { principles } \\
\text { to teaching }\end{array}$ & $\begin{array}{l}\text { Blog reveals } \\
\text { students adopting } \\
\text { LOC principles } \\
\text { and digital } \\
\text { literacy in their } \\
\text { teaching but } \\
\text { students' } \\
\text { acknowledgement } \\
\text { of the blog } \\
\text { assisting this has } \\
\text { decreased. }\end{array}$ & $\begin{array}{l}\text { Range of } \\
\text { learning } \\
\text { strategies } \\
\text { modeled } \\
\text { through blog } \\
\text { content, e.g. } \\
\text { socio } \\
\text { constructivist }\end{array}$ \\
\hline $\begin{array}{l}\text { Phase 3: Blog } \\
\text { content } \\
\text { compared } \\
\text { with the open } \\
\text { coded themes } \\
\text { of the focus } \\
\text { group }\end{array}$ & $\begin{array}{l}\text { 1. Learning } \\
\text { through the } \\
\text { foundation } \\
\text { curriculum } \\
\text { shared }\end{array}$ & $\begin{array}{l}2 . \\
\text { Organisation } \\
\text { of learning } \\
\text { articulated }\end{array}$ & $\begin{array}{l}\text { 3.Technology } \\
\text { enhanced } \\
\text { learning } \\
\text { discussed }\end{array}$ & $\begin{array}{l}4 . \\
\text { Learning } \\
\text { outside the } \\
\text { classroom } \\
\text { principles } \\
\text { articulated }\end{array}$ & & \\
\hline $\begin{array}{l}\text { Focus group } \\
\text { findings }\end{array}$ & $\begin{array}{l}\text { Shift from } \\
\text { learning about } \\
\text { the principles } \\
\text { to modeling in } \\
\text { practice }\end{array}$ & $\begin{array}{l}\text { Students } \\
\text { share value of } \\
\text { blogging }\end{array}$ & $\begin{array}{l}\text { Student value } \\
\text { of technology } \\
\text { increased }\end{array}$ & $\begin{array}{l}\text { Students } \\
\text { identify } \\
\text { LOC } \\
\text { practices } \\
\text { enhancing } \\
\text { pupil } \\
\text { learning }\end{array}$ & & \\
\hline $\begin{array}{l}\text { Evidence on } \\
\text { the blog that } \\
\text { correlated } \\
\text { with the } \\
\text { theme. }\end{array}$ & $\begin{array}{l}\text { Principles } \\
\text { modeled in } \\
\text { practice: } \\
\text { digital content/ } \\
\text { plans }\end{array}$ & $\begin{array}{l}\text { Evidence in } \\
\text { narrative }\end{array}$ & $\begin{array}{l}\text { Use of in own } \\
\text { teaching/ blog } \\
\text { content }\end{array}$ & $\begin{array}{l}\text { Visuals } \\
\text { Plans/ } \\
\text { Evaluations }\end{array}$ & & \\
\hline
\end{tabular}

Within figure 1 above three key themes are identified which informed our strategy for analysing multi-modal content on blogs and communities. The literature justifying the selection of these components is now explained. Further discussion of the data shared in figure 1 follows this.

\section{Communities of Practice}


According to Lave and Wenger's definition, 'Communities of practice are groups of people who share a concern or a passion for something they do and learn how to do it better as they interact regularly.' (Wenger, 2011, p.1). Other definitions place a similar emphasis on applying knowledge to practice, viewing communities as 'individuals united in action' (Liedka, 1999, p5) or as groups with similar aims purposefully solving authentic problems within a real world context (Wick, 2000; Johnson, 2001). Since Wenger's original work on communities of practice in 1991 there has been a widespread increase in online learning, which has resulted in the adoption of the term ' online communities of practice' to describe 'sociotechnological learning environments' that facilitate knowledge construction (Ozturk and Ozcinar, 2013).

The case studies shared in this paper enable participants to belong to online communities of practice with a shared common purpose in improving their classroom pedagogies. Our learners were able to co-construct knowledge by documenting learning that took place in a number of different contexts: at teacher sharing events, at network meetings, in classrooms, and via the creation of digital artefacts. Contemporary online communities of practice, such as those modelled, can thus combine physical and virtual spaces enabling the participants' learning journeys to move in and out of a number of 'habitats', a process which increases the opportunities for learning (Wenger, White and Smith, 2009; Hammond, 1998). This generated some key questions for us; when participants of the communities of practice navigate these habitats how does the learning itself take place and how can educators facilitate this learning to move forward? These questions prompted an interest in reflexivity.

\section{Reflexivity to Facilitate Learning}

When blogs and communities are used in educational contexts it is our belief that they fuel reflexivity. We are basing our discussion on the premise that reflexivity is about validating self knowledge (Grushka, 2005) and that it is a process that enables us to reflect on and learn from the experiences we encounter. In a teaching context, reflexivity can enable 'practitioners to identify, understand and act in relation to the personal, professional and political challenges they face in practice.' (Alley et al, 2015, p. 426). It is known that reflexive dialogue can create fluidity in interactions (Scott and Morrison, 2005) and that it can aid the expression of cause and effect experiences (Spry, 2001). We were interested in how visual reflexivity within the multimodal content that was posted on our blogs and communities might increase the transfer of ideas to practice (Ortlipp, 2008). It was also of interest how participants interact with the multimodal content to generate reflexive discussion.

\section{Innovative Technology to Support Teaching and Learning:}

With blog and community participants posting multi-modal content, one must question which technologies are being used and their influence on the progression of teaching and learning, so that an understanding can be sought concerning the benefits and limitations of the application of technologies in modelling the 
learning process. There is abundant research in teacher education (Stobaugh and Tassell, 2011; Donohue and Fox, 2012) and school pedagogy (Reedy, 2008;

Rohaan, Taconis and Jochems, 2010) about the use of innovative technologies to progress learning, however there is less documentation of how within communities of practices teacher educators can model innovative or creative uses of technology to reflect on their own practice or model best pedagogical practice to others, entities we believe are essential to moving learning in teacher education forward. Innovation is an elusive concept and what is innovative to one setting may not be to another. In our five case studies, we chose to emphasise the practical application of ideas, echoing Denning's definition of innovation as 'the adoption of a new practice in a community' (Denning 2004) and Gulbrandsen and Aanstad's (2014) suggestion that innovation is something new that is put to practical use.

\section{Five Cases Utilising Blogs and Communities In Teacher Education}

\section{The Methodology}

Our research design is focused around the analysis of multimodal content in five blogs and communities to examine the common, successful and limiting factors in enhancing learning through the three themes of communities of practice, reflexivity and use of technology. Before undertaking an analysis across our five cases it was necessary for us to determine how student learning occurred in one example. Case two models our methodological structure for this individual blog analysis, sharing how our conclusions in specific cases have been drawn. Table 1, demonstrates how the multi-modal component of the blog was analysed. To achieve analysis across all of the blogs we applied our conceptual coding framework, Table 2, to each blog or community and documented any occurrences where the content provided a model of key codes.

Difficulties encountered included the quantity of data shared, its multimodal nature and the influence of audience perception, due to data being interpreted in diverse ways. To counteract these concerns sample posts within each blog or community were focused on for analysis. Where media content was explored random excerpts, short frames and visuals were selected to provide a content overview and to counteract misinterpretation. Content was analysed by more than one individual, limiting issues associated with interpretation and distortion (McNiff, 2011; Rose, 2012). The conceptual frame proved a useful tool because it kept the entities we were looking for focused whilst providing a method of theory based sampling (Silverman, 2013). To develop the methodological strength of our research we could have limited it to just one component of the content posted, such as the written discussion, but it was agreed that the multimodal content is the common language of these contemporary technological tools (Sullivan, 2010). We have aimed to discuss the context associated with the data in order to increase the accessibility and ultimately validity of our research (Pink, 2003). 
The coding strands used for analysis focused on the demonstration of reflexive learning (Schon, 1983), identifying where content facilitated the creation of socially shared content and learning communities (Deng and Yuen, 2013; Yang 2009), where posts modelled self-directed learning (Farmer, Yeu and Brooks, 2007) and where evidence was provided of participants immersing themselves in technology-based learning practices (Sharples et al., 2014). We determined this to mean using a technological tool that had not previously been encountered or where a tool was used in a different way to those modelled in course sessions. Once coding had occurred in relation to each case we were able to look at the correlations between cases as identified Table 2 .

Before our overarching findings are communicated and Table 2 explained we provide an overview of each case to reveal the stories behind our research and illustrate how they relate to the literature.

\section{Case 1: A module blog in art education}

This case models how a group blog was implemented as a non-assessed component on our ITE art specialism course (see Figure 1 below). Upon analysis of this case, findings revealed that student learning was influenced by the participants' ability to become co-producers of content (Deng and Yuen, 2013). The blog enabled learners to express their artistic and educational license; the participants did not write all of the blog posts, some were created by the course tutor but learners created the visual content and made comments on session posts, showing reflexive engagement. Through engagement in a community of practice on the blog, learners became aware of what it meant to share their practice as an artist teacher in a public domain (Parker, 2009; Stanhope, 2011) moving their understanding of pedagogy forward. As their familiarity with the blog developed, they began to generate discussion surrounding their content, demonstrating creative design cognition through their digital narratives (Tillander, 2011).

A barrier to learning in this case was the disparity in student confidence to engage with the blog, but as Muncy (2014) stated, this developed when the students' familiarity with the blogging process grew. When the blog was used as a tool for discussion and content sharing in taught sessions a model of interaction was provided by the tutor; she provided a scaffolded environment for them before independent engagement with the blog occurred.

Figure 1. Case 1 Blog url and a sample digital artefact from the art education module blog 


\section{Case 1: http://mypad.northampton.ac.uk/artspecialism2014/}

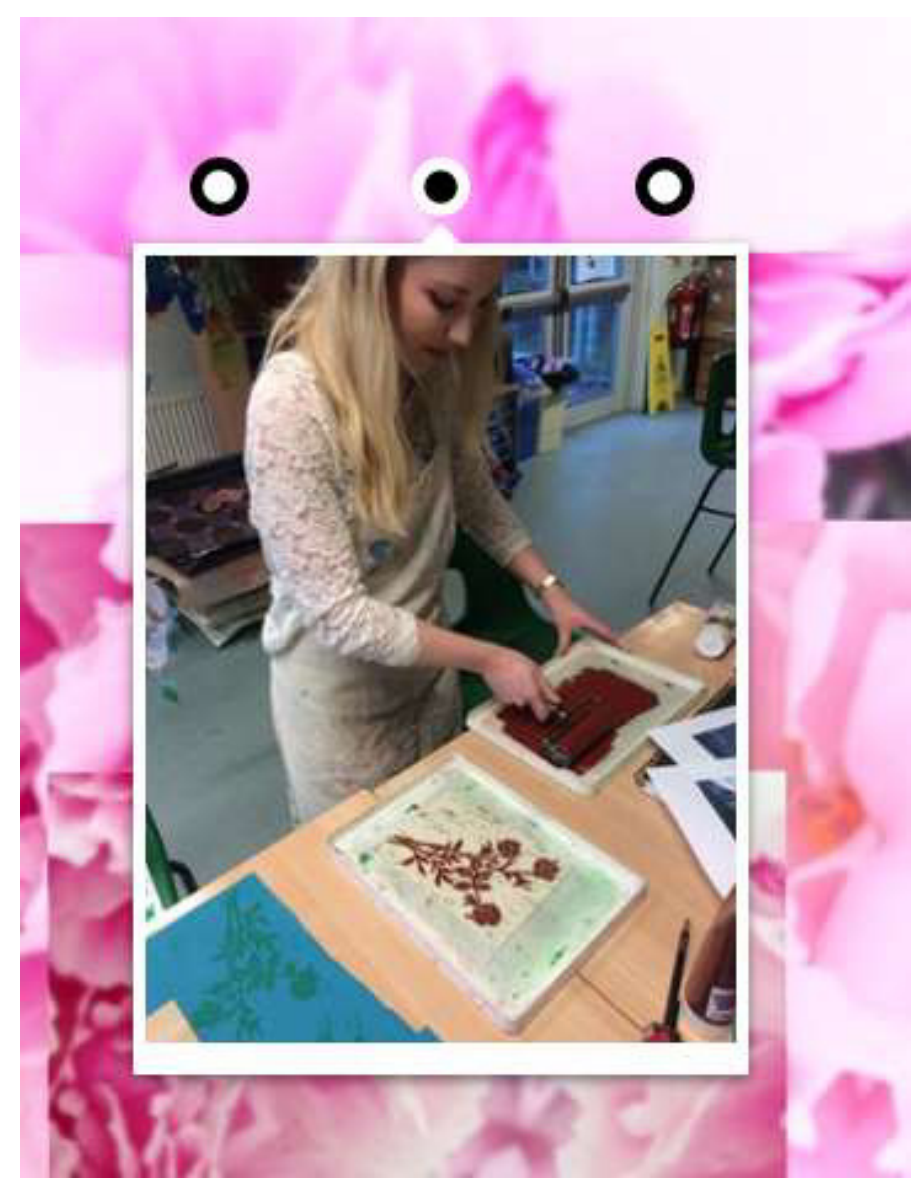

The blog highlights the importance of analysing visual or multimodal contributions, wherein the visual content represents the voice of the learner. As an example shared in figure 1 above, one student has posted on the blog to reflect on her growing understanding of art education, she used two technologic tools: Answer Garden (https://answergarden.ch/view/218945) and Thinglink (https://bit.ly/1RJD7xt ). The combination of tools meant that she was able to document her learning journey using a word cloud, images, video and text, and then share it so that her tutor and peers could respond. This resonates with the idea of the 'Patchwork Text' (Winter, 2003) as an approach to assessment in Higher Education which recognises the value of students using a diverse range of media to document and share their learning journeys. In comparison with the traditional essay format this approach emphasises the process of 'becoming' over the idea of subject mastery, (Ovens, 2003). We would agree with Ovens (2003) that the opportunities for subjectivity and dialogue that this approach affords sets the stage for deep learning and the necessity for a revaluation of acknowledged learning strategies in teacher education. This finding sets the stage for the analytical approach we adopted in Case 2. 


\section{Case 2: Student group blogs to explore learning outside the classroom pedagogy}

This case provides a second example of group blogs supporting learning in ITE, in this instance as an assessed piece of work produced by groups of four students. This case was developed into a fuller analysis, which has informed our review of all five cases. We share this to showcase the complexities of blog analysis and demonstrate stage 1 of our methodology.

In this case, blogs were used as an assessment tool to demonstrate how PGCE students applied a learning outside the classroom (LOC) approach to study foundation subjects in the UK National Curriculum (DfE, 2013). The students created blogs over the course of an academic year documenting reflection on their own learning experiences of LOC practices. Over time, the students' reflection occurred both in action, on action and for action (Schon, 1983; Cowan, 2006) as they refined ideas through site visits, on campus and during school placements. A 'magazine-style' blog format supported reflexive learning as students were able to document team meetings through journal postings. They also shared draft ideas for using technology tools such as a QR code trail and an interactive map before refining their plans as a group. This demonstrated a high degree of self directed learning as they actively explored ways to use technology to provide opportunities for children to build upon their outdoor experiences. Students then used the static pages option on the blogs to present summaries of their learning in the form of lesson plans, a theoretical rationale and a group presentation, this can be viewed by following the blog url in figure 2 .

Figure 2. Case 2 Blog url and sample page to demonstrate how student group blogs were used to explore learning outside the classroom pedagogy

Case 2: http://mypad.northampton.ac.uk/parkrangers/ 


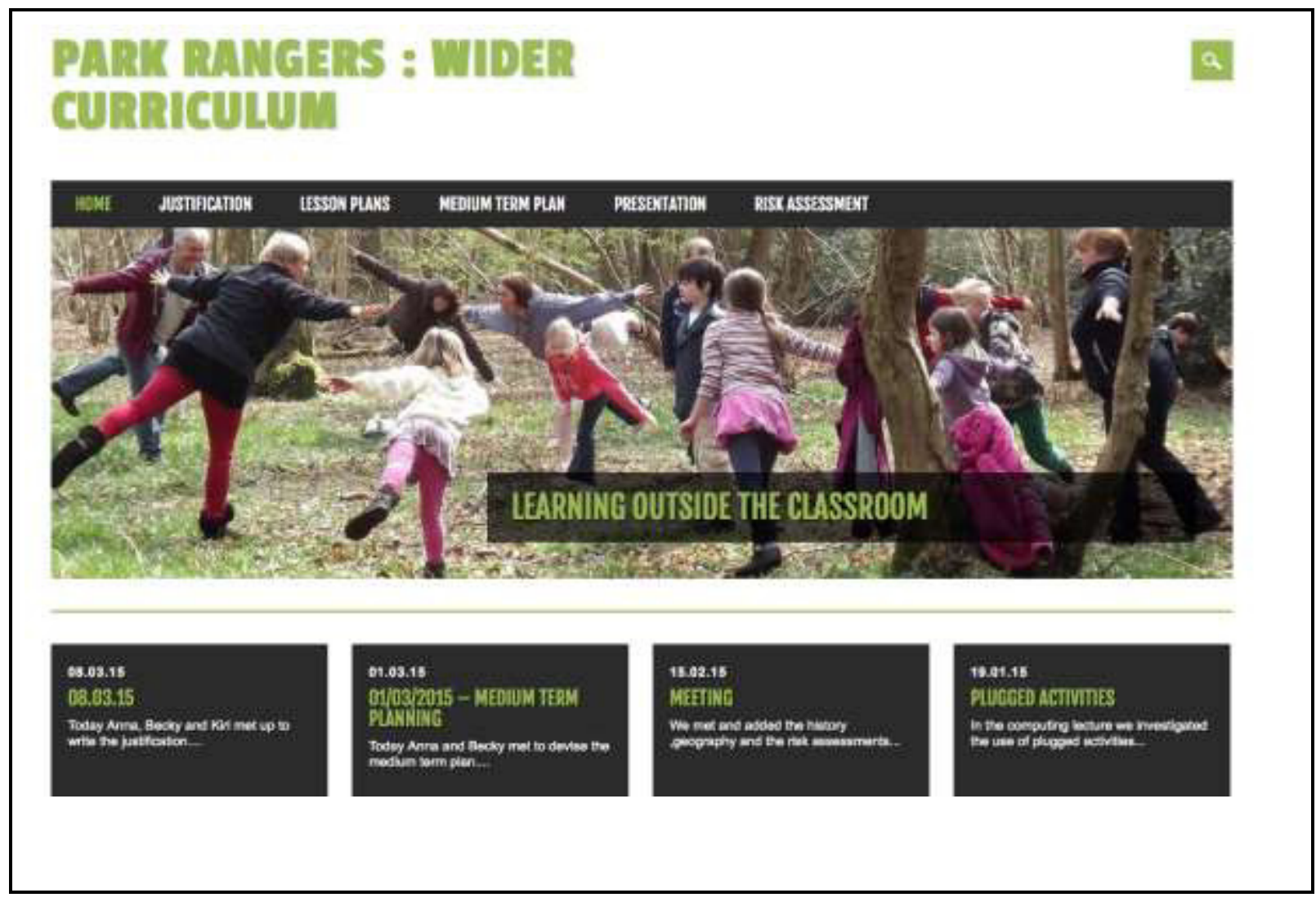

In this case study, we took a triangulated approach to the blog analysis. Our curriculum team conducted pre and post learning questionnaires and pre and post focus groups with our students, and analysed these to generate key themes. Open coding was used to determine the focus group themes. We analysed the findings from these against blog contributions to determine how student learning developed. When analysed against their blog contributions a sequential threestage process was used. Figure 1 shared previously documents the coding phases used and the key learning themes generated as a result of the questionnaires and focus groups. It provides a small number of examples to model how this evidence was identified on the student blogs.

The strength of the approach adopted in Figure 1 was that blog analysis revealed additional findings to the questionnaire and focus group, as it was able to take account of the multimodal content. The blog content helped to substantiate students' comments increasing data validity. Enhanced opportunities for reflection, collective knowledge building and the use of technology were emerging themes from this analysis. The reflexive process used by the students in the blogs enabled a cyclical process of learning to occur (Kolb, 1994). The students were able to use the blog to reform their thinking around LOC practices and implement new actions as a result. As academics we also engaged in reflexive learning, maintaining empathy with the students' growing integration of theory and practice. As a result, the blogs documented the growth of students' confidence and understanding of LOC practices and digital media over time, and 
enabled students to review and adapt their learning in response to influences from scholarly material (Brown, 2004).

As with the blog in case 1, the research revealed an initial reluctance to engage in blogging. However, by the end of the assessment process students could see how their blogs had enhanced their understanding of LOC practices and identified that blogging would be valuable to their learners. As academic practitioners we recognised that the learning process might be enhanced if students were taught how reflexive dialogue could enhance learning. Academic staff took account of how blogs gave a more central role to student voice, positioning the students as educational change-makers (Hood, 2008).

\section{Case 3: Northampton Inspire: A teacher CPD blog and Google + $(\mathbf{G +})$} community spanning geographical locations The combination of a blog and a $\mathrm{G}+$ community in case 3 provides an example of how school pupils, university students, teachers and academics can engage in collective knowledge-building around a common purpose: in this case the creative exploration of technology and the arts. This blog extends the learning practice shown in case 2, as it demonstrates the use of blogs and communities in tandem to support a dispersed network group of educators who are engaged in developing and evaluating their practice. The blog provided a connected environment in which the community could build an evidence base of best practice in teaching with technology by archiving their learning experiences. This was complemented by the community space as a fertile ground for ongoing discussion and ideas sharing. An advantage of using two online spaces in this way was the facility for educators to build upon each others' ideas and strategies.

Figure 3. Case 3 Blog url and Google+ community for Northampton Inspire CPD group and sample project page 


\section{Case 3:}

Blog url: http://mypad.northampton.ac.uk/inspire/

G+ community: https://bit.ly/1PxGxmZ

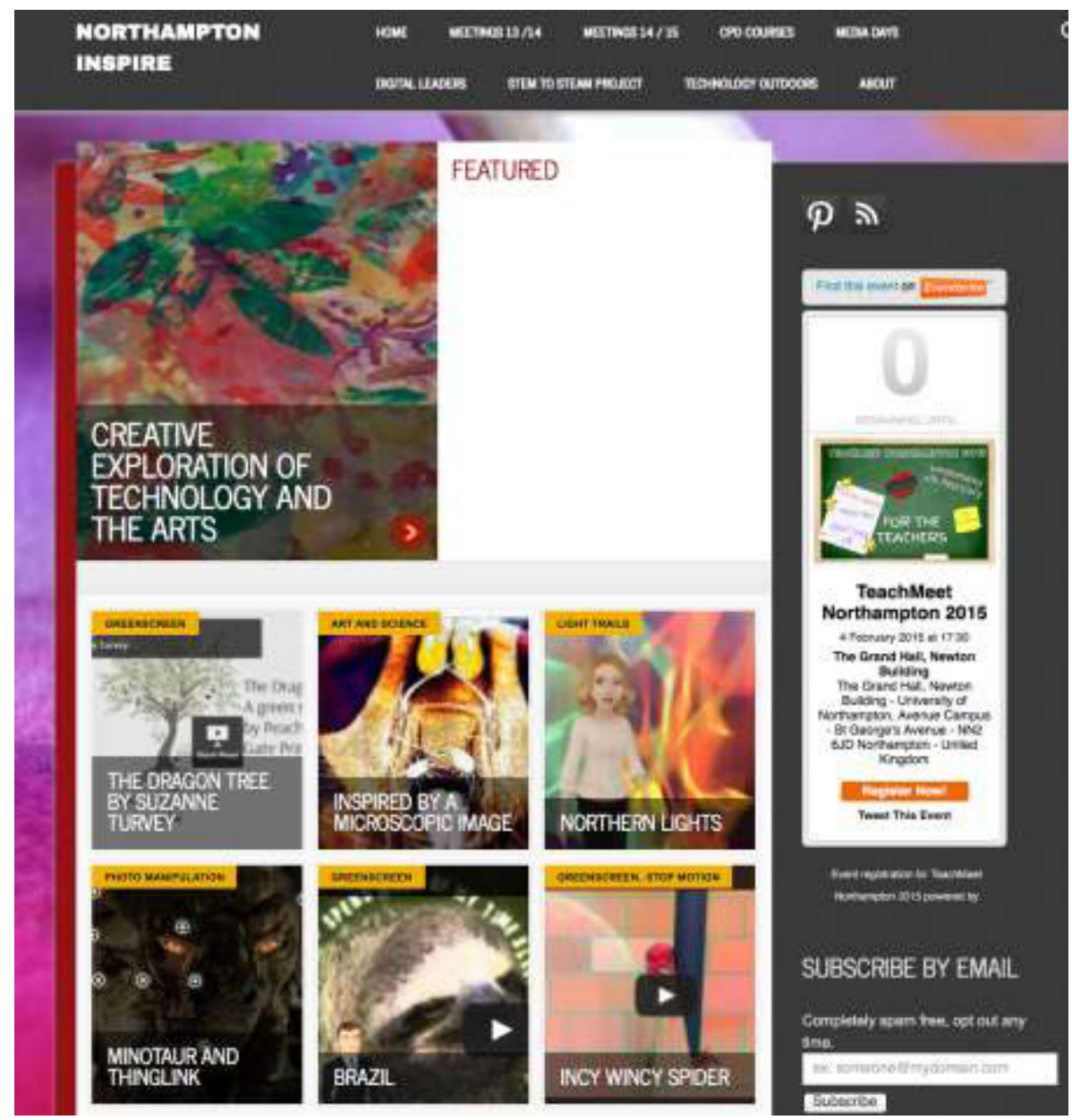

To look at one example shared, the idea of using a 'light trails' app was picked up from a network meeting, applied in one primary school to support science, in another as an art project, and in a special school to promote multisensory learning. Teachers' reflections on this approach were recorded at a TeachMeet and on Twitter, and shared on the blog as a video recording and Storify. The teachers used these tools to actively engage in reflexive learning using innovative technologies.

In a second example a teacher shared ideas for making model birds using sound, images and text through the app Explain Everything (http://bit.ly/11LTI5z ).This theme was developed via comments and postings on the G+ community, resulting in a face to face learning event for teachers, academics and children entitled 'Forest

Flight', based on the idea of deconstructing technology devices to make singing bird sculptures. The event was captured on the group blog (http://bit.ly/1ZZM0b1 ) and has inspired similar projects in local schools. A key aspect of this collaborative 
process was the agility with which ideas could be conveyed and refined through media-rich postings on the community.

The above example illustrates the way in which blogs and communities worked in tandem to support cycles of learning across learning habitats, with teachers refining ideas on $\mathrm{G}+$ and then using the blog as a repository for archived projects. Used together, the blog and community enabled educators from a range of settings to discover common ground as they applied ideas to practice across varied contexts, a benefit suggested by Wick (2000), which is also modelled in the students' practices in cases 1 and 2. Researchers have noted a difference between the physical and virtual communities in the absence of 'traditional group norms' and the levelling of social hierarchies (Palloff and Pratt, 1999). In cases 1 and 3, contributions from students sit side by side with posts and comments by academics, cutting across formal structures and forging new understandings across educational sectors of the ways in which technologies can transform learning (Wenger, 2011).

\section{Case 4: The ipad project - a blog and community to enhance mobile learning in Higher Education}

This case demonstrates the way in which our growing community of practice involving academic staff in teacher education has developed shared metacognition as outlined by Gunwardena (Gunawardena et al., 2009) around the theme of mobile learning. Mason and Rennie describe this type of learning shift as 'group mediated cognition' in which 'knowledge is created, shared, remixed, repurposed, and passed along.' (2008, p.10). Our community demonstrates this as it documents the evolution of participants' use of a core set of apps for content creation over the course of a year with tools such as Thinglink, Skitch, Padlet, Rollworld, Explain Everything and Visual Poet being reused to meet a range of learning objectives across different subject areas within the group. A shared consensus has emerged that apps such as these can help make students' learning more visible. As the group solved problems together, sought help from each other, reused solutions and evaluated new apps, they developed a 'collective competence' and a shared repertoire of resources and strategies (Wenger, 2011, p.1-6).

In this example, four academics build a shared understanding of how the app Aurasma might be used in their teaching through a combination of a posted image and an exchange of comments (http://bit.ly/1S79UNu).

Figure 4. Case 4 Blog url and Google+ community to enhance research and CPD in Higher Education accompanied by a sample of a Google+ page for our iPad case study. 


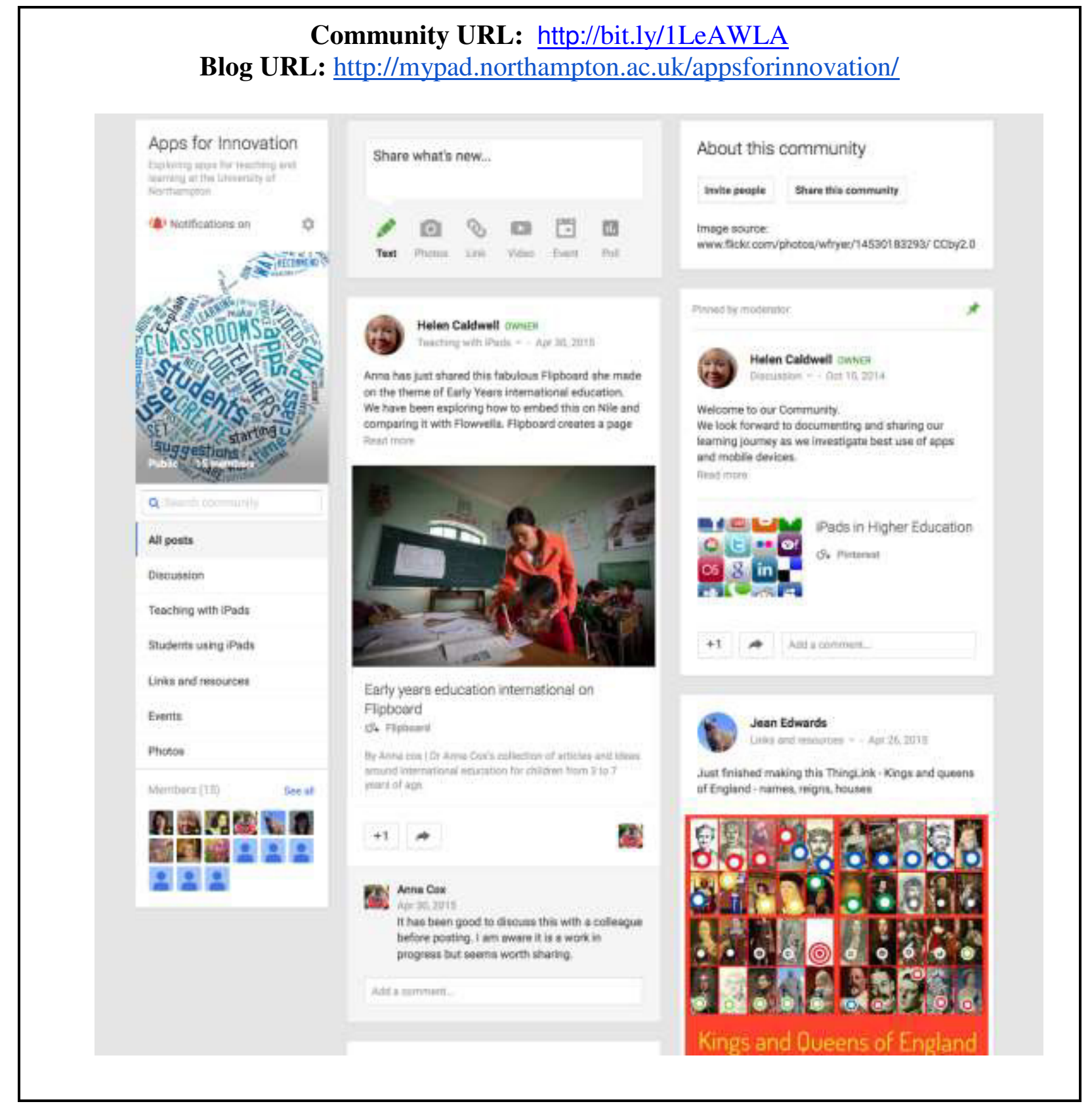

As in case 3, we have combined remote and physical collaboration by mixing occasional face-to-face contact with connected conversations through social media. Our cases can thus be seen as connectivist learning environments in which participants make connections with people and resources, co-create ideas and make choices within an environment mediated by technology (Saadatmand and Kumpulainen, 2014; Downes, 2010; Siemens, 2005). We would agree with Anderson and Dron that the sharing of visual digital artefacts is key, "Connectivist models explicitly rely on the ubiquity of networked connections between people, digital artefacts, and content" (Anderson and Dron, 2011, p. 87). 
Unlike face-to-face learning events where a cohort learns the same content at the same pace, an online community may have different types of participation and differing degrees of expertise. Wick (2000) notes that collaborative teams might form and dissolve resulting in cross-pollination of ideas. In the community of Case 4, this can be seen around the apps for art activities bringing together the 'app smashing' combination of Rollworld, Fragment and BeFunky, which has been independently explored by three academics and has resulted in several related posts and a series of comments on the blog and community.

A benefit of online learning is identified here; learning opportunities are multiplied as the collective learning potential of the group exceeds that of the individual working on their own and can thus lead to accelerated learning (Richardson, 2010; Hung, 2002). Johnson highlights this as a key idea when saying, "The learning that evolved from these communities is collaborative, in which the collaborative knowledge of the community is greater than any individual knowledge" (Johnson, 2001, p34). We would echo that this has been a major learning potential of the use of blogs and communities in our higher education courses and highlights a key advantage of practice for other institutions.

\section{Case 5: A digital community to support SEN education}

This case focuses on the use of a $\mathrm{G}+$ community to support an undergraduate module in Assistive Technology. Case 5 illustrates how students contributed to the online community before, during and after our face-to-face sessions. Luckin et al, (2010) noted that this self-directed involvement by the participants is crucial to the success of the community and suggests that it can integrate formal and nonformal modes of learning by motivating learners to take a self-directed approach to managing their digital learning as they curate resources, reflect upon achievements and offer contributions to others.

Figure 5. Case 5 Community url to support a student module in SEN education and a sample webpage which supports an assistive technology case study 


\section{Case 5:}

Community URL: http://bit.ly/1S7a7Aq

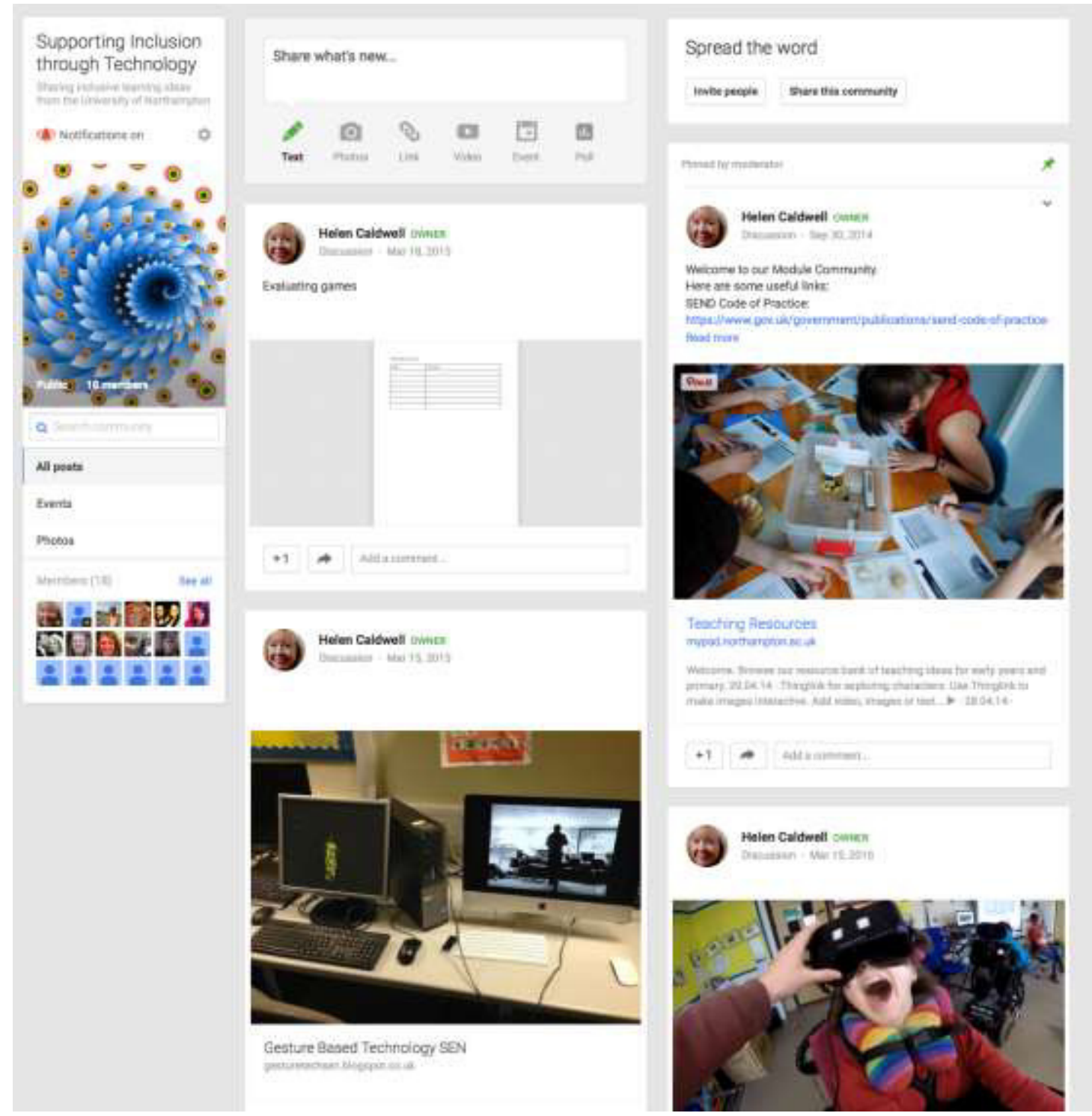

In case 5 we aimed to create an online classroom where interactions occurred beyond the face-to-face sessions in order to make a more seamless connection between online and offline learning. We sought to capture ideas during sessions using collaborative tools such as Google Docs and Padlet so as to enhance this connection. We wanted to emphasise the inclusivity of the approach by encouraging students to express their understanding in diverse ways, as well as to offer visual and auditory access to topics. This was so that our students gained first hand experience of how these approaches might benefit the SEND users they 
would need to support in their future practice. We looked to increase student collaboration so that they approached each other for feedback rather than just their tutors. We hoped students would see the value in belonging to a community of practice in their field, in the same way as our Higher Education staff had identified through our iPads in HE project in case 4.

\section{Analysing Learning Themes Across Blogs and Communities}

With our observations from practice and readings from the literature in mind, as explained in our methodology we undertook a structured analysis of learning themes across our online spaces to seek evidence of their efficacy. Through our five case studies we sought to compare how they represented our key coding themes. We looked at how these themes differed across the blogs and G+ communities. Table 2 below shows some examples drawn from both tools, colour coded to show examples from blogs and $\mathrm{G}+$ communities.

Table 2

Examples of themed analysis across the five5 blog and community cases

\begin{tabular}{|c|c|c|c|c|c|}
\hline \multirow{3}{*}{$\begin{array}{c}\begin{array}{c}\text { Overview of examples across } \\
\text { blogs and communities }\end{array} \\
\end{array}$} & \multicolumn{5}{|c|}{\begin{tabular}{l}
\multicolumn{2}{c}{ Coding themes } \\
Communities Blogs
\end{tabular}} \\
\hline & \multicolumn{2}{|c|}{ Reflexivity } & \multicolumn{2}{|c|}{ Communities of Practice } & \multirow{2}{*}{$\begin{array}{c}\text { Technologic Innovation } \\
\begin{array}{c}\text { Innovative use of } \\
\text { technology. }\end{array} \\
\text { (Sharples et al. 2014) }\end{array}$} \\
\hline & $\begin{array}{l}\text { Reflective learning } \\
\quad \text { (Schon, 1983) }\end{array}$ & $\begin{array}{l}\text { Self-directed } \\
\text { learning } \\
\text { (Farmer, Yeu } \\
\text { and Brooks, } \\
\text { 2007) }\end{array}$ & $\begin{array}{c}\text { Socially shared } \\
\text { content } \\
\text { (Deng and } \\
\text { Yuen, 2013) }\end{array}$ & $\begin{array}{l}\text { Learning } \\
\text { communities } \\
\text { (Yang, 2009) }\end{array}$ & \\
\hline $\begin{array}{l}\text { Case Study 1: A module blog for } \\
\text { students in art education } \\
\text { http://mypad.northampton.ac.uk/a } \\
\text { rtspecialism2014/ }\end{array}$ & $\begin{array}{l}\text { Reflecting on } \\
\text { school/ gallery } \\
\text { visits }\end{array}$ & $\begin{array}{l}\text { Making } \\
\text { connections } \\
\text { between own } \\
\text { practice and } \\
\text { other artists' } \\
\text { work during } \\
\text { gallery visits }\end{array}$ & $\begin{array}{l}\text { Using blog tags, } \\
\text { blogroll and } \\
\text { categories to } \\
\text { improve } \\
\text { navigation } \\
\text { Hosting an } \\
\text { exhibition }\end{array}$ & $\begin{array}{l}\text { Documenting a } \\
\text { social issues } \\
\text { exhibition } \\
\text { Responding to } \\
\text { discussion } \\
\text { topics }\end{array}$ & $\begin{array}{l}\text { Pre-session readings and } \\
\text { tasks: blended learning } \\
\text { Digital making }\end{array}$ \\
\hline $\begin{array}{l}\text { Case Study 2: } \\
\text { Student group blogs to explore } \\
\text { learning outside the classroom } \\
\text { http://mypad.northampton.ac.uk/p } \\
\text { arkrangers/ }\end{array}$ & $\begin{array}{l}\text { Updates of } \\
\text { information } \\
\text { Transfer of learning } \\
\text { to a new setting or } \\
\text { scenario }\end{array}$ & $\begin{array}{l}\text { Application of } \\
\text { LOC principles } \\
\text { to teaching } \\
\text { Relating } \\
\text { practice to } \\
\text { theory }\end{array}$ & $\begin{array}{l}\text { Creation of } \\
\text { resources/ } \\
\text { lesson plans for } \\
\text { other students } \\
\text { Presentation } \\
\text { software used }\end{array}$ & $\begin{array}{l}\begin{array}{l}\text { Students } \\
\text { reviewing } \\
\text { information }\end{array} \\
\begin{array}{l}\text { Delegating roles } \\
\text { within a group }\end{array} \\
\begin{array}{l}\text { Working in } \\
\text { partnership with } \\
\text { museums }\end{array}\end{array}$ & $\begin{array}{l}\text { Use of external e-tools e.g. } \\
\text { thinglink, QR codes } \\
\text { Uploading and manipulating } \\
\text { own digital content }\end{array}$ \\
\hline $\begin{array}{l}\text { Case Study 3: A teacher CPD } \\
\text { blog and G+ Community } \\
\text { http://mypad.northampton.ac.uk/i } \\
\underline{\text { nspire/ }} \\
\text { https://plus.google.com/u/0/comm } \\
\text { unities/116085017840955911437 }\end{array}$ & $\begin{array}{l}\text { Reflecting on the } \\
\text { creation of } \\
\text { collaborative visual } \\
\text { minutes of an event }\end{array}$ & 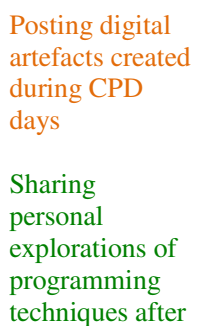 & $\begin{array}{l}\text { Posting details } \\
\text { of events } \\
\text { Sharing } \\
\text { Pinterest boards } \\
\text { of ideas on } \\
\text { session themes }\end{array}$ & $\begin{array}{l}\text { Posting videos } \\
\text { of event } \\
\text { presentations } \\
\text { Suggesting } \\
\text { further } \\
\text { applications of } \\
\text { techniques }\end{array}$ & $\begin{array}{l}\text { Crowd based learning at a } \\
\text { TeachMeet event: event- } \\
\text { based learning } \\
\text { Documenting network } \\
\text { meetings and providing pre } \\
\text { and post meeting resources: } \\
\text { flipped learning }\end{array}$ \\
\hline
\end{tabular}




\begin{tabular}{|c|c|c|c|c|c|}
\hline & & $\mathrm{CPD}$ events & & & $\begin{array}{l}\text { Creating animated gifs to } \\
\text { demonstrate techniques }\end{array}$ \\
\hline $\begin{array}{l}\text { Case Study 4: A HE CPD blog } \\
\text { and G+ community } \\
\underline{\text { https://plus.google.com/u/0/comm }} \\
\underline{\text { unities/110218249780833007111 }} \\
\text { http://mypad.northampton.ac.uk/a } \\
\text { ppsforinnovation/ }\end{array}$ & $\begin{array}{l}\text { Using the blog to } \\
\text { write reflective } \\
\text { posts after } \\
\text { application to } \\
\text { practice and } \\
\text { identifying } \\
\text { improvements and } \\
\text { extensions }\end{array}$ & $\begin{array}{l}\text { Posting reviews } \\
\text { comparing apps } \\
\text { Taking } \\
\text { recommended } \\
\text { apps and } \\
\text { applying them } \\
\text { to own teaching } \\
\text { Writing a } \\
\text { blogpost that } \\
\text { documents } \\
\text { personal } \\
\text { exploration of } \\
\text { iPad } \\
\text { accessibility } \\
\text { options and } \\
\text { generalising } \\
\text { from the } \\
\text { experience }\end{array}$ & $\begin{array}{l}\text { Making } \\
\text { suggestions for } \\
\text { extending } \\
\text { participants } \\
\text { posts on uses of } \\
\text { apps across } \\
\text { other subjects } \\
\text { Suggesting } \\
\text { questions to } \\
\text { investigate and } \\
\text { avenues for } \\
\text { further research } \\
\text { as part of blog } \\
\text { posts }\end{array}$ & $\begin{array}{l}\text { Responding to } \\
\text { queries on the } \\
\text { community } \\
\text { Building shared } \\
\text { strategies for re- } \\
\text { using } \\
\text { recommended } \\
\text { apps in different } \\
\text { learning } \\
\text { contexts } \\
\text { Posting in pairs } \\
\text { to record } \\
\text { discussions } \\
\text { Creating } \\
\text { screencasts to } \\
\text { enable others to } \\
\text { replicate app } \\
\text { uses }\end{array}$ & $\begin{array}{l}\text { Collaborating on a shared } \\
\text { Prezi conference presentation } \\
\text { Developing app flows } \\
\text { combining tools to enhance } \\
\text { app capabilities }\end{array}$ \\
\hline $\begin{array}{l}\text { Case Study 5: A G+ community } \\
\text { to support a student module in } \\
\text { SEN education } \\
\text { https://plus.google.com/u/0/comm } \\
\text { unities/105048363469375309187 }\end{array}$ & $\begin{array}{l}\begin{array}{l}\text { Group evaluations } \\
\text { of games based } \\
\text { learning } \\
\text { experiences, }\end{array} \\
\text { Group app reviews } \\
\text { Posting reflections } \\
\text { and images after } \\
\text { visits to settings and } \\
\text { visits from } \\
\text { practitioners } \\
\text { Capturing student } \\
\text { debate }\end{array}$ & $\begin{array}{l}\text { Creating } \\
\text { applications for } \\
\text { symbol-based } \\
\text { learning } \\
\text { Uploading } \\
\text { reflections on } \\
\text { wider browsing } \\
\text { Sharing } \\
\text { personal } \\
\text { reviews of } \\
\text { accessibility } \\
\text { options across } \\
\text { devices }\end{array}$ & $\begin{array}{l}\text { Sharing } \\
\text { slideshows } \\
\text { evaluating } \\
\text { acoustic } \\
\text { environments } \\
\text { around the } \\
\text { university } \\
\text { Sharing images } \\
\text { and evaluations } \\
\text { of assistive } \\
\text { technologies for } \\
\text { the visually } \\
\text { impaired }\end{array}$ & $\begin{array}{l}\text { Posting and } \\
\text { commenting on } \\
\text { personal } \\
\text { browsing on } \\
\text { session themes } \\
\text { Commenting on } \\
\text { posts } \\
\text { Sharing tips for } \\
\text { exploring } \\
\text { multisensory } \\
\text { equipment with } \\
\text { darkrooms }\end{array}$ & $\begin{array}{l}\text { Using collaborative Google } \\
\text { Docs to record group } \\
\text { discussions } \\
\text { Making multimedia digital } \\
\text { artefacts } \\
\text { Using QR codes }\end{array}$ \\
\hline
\end{tabular}

Table 2 suggests that blogs and G+ communities are both useful tools for demonstrating reflective and self-directed learning. They enable the generation of socially shared content within learning communities, and promote the use of technology-based teaching practices. When blogs and communities are used in combination, as in cases 3 and 4, they can encourage reflection before, during and after the application of theory to practice adding reflexive learning. By observing how blogs and communities can be used together our analysis emphasises the twin aims of generating content through interaction and curating content in a 'communal repository' to use Wenger et al.'s term (2009, p.1). We suggest that the sharing of multimodal content makes these aims more achievable by using media to transmit explicit and succinct examples of classroom practice and subsequently provides opportunities for students to interact with shared content. 
When further supported by face-to-face events, blogs and communities can promote continuous learning through active experimentation and sharing within the online community (Kolb, 1984; Schon, 1983). Our findings suggest that reflexive cyclical learning occurs across habitats as ideas are picked up by peers, responded to and reinterpreted in the form of new digital artefacts. This process gave our participants the confidence to try technological approaches in their own teaching contexts, easing the transfer of technologic innovation to classroom practice.

\section{Conclusions}

Through our cases we have shown that online communities of practice in the form of blogs and communities, such as $\mathrm{G}+$, can provide a fertile ground for social learning. Like their physical counterparts, our virtual communities of practice are characterised by a shared common purpose and by the application of ideas to practice.

Our belief, supported by our findings to date, suggests that reflexive learning can be amplified and accelerated due to the number of opportunities learners have to engage with others who are exploring the same topics in different contexts.

Our discussion of blogs and communities highlights the value of mixing physical, digital and social learning spaces. And it also demonstrates the potential of digital technology to support individual learners in a personalised way, recognising the value of documenting personal learning through a range of media 'as it happens' rather than demonstrating mastery of a field through a text-based assignment at the end of a module (Ovens, 2003).

\section{Next Steps}

We have taken steps towards developing a framework for analysing our multimodal blog and community posts. Our next step is to apply this methodology across more cases in order to match learning themes and digital tools to provide further evidence of how multimodal online spaces promote the transfer of pedagogy to practice.

The emphasis of our cases has been on active knowledge building using collaborative technologies, moving away from teacher-directed pedagogy to a flexible learner-directed approach (Hung, 2002; Markham, 2003). Future studies might investigate further the facilitator's role in scaffolding learning by posting questions and content and making the learning process within the communities more explicit. Cases might consider how the Pedagogy-Andragogy-Heutagogy (PAH) continuum suggested by Luckin et al. (2010) might offer a useful way of considering the redefinition of teacher-learner roles in this context.

Our longer term aim is to document fluid and continuous learning journeys across locations, times, technologies and social settings in higher education and to identify their effect on student learning to illuminate the practices we have 
modelled here. We agree with Wenger et al., (2009, p.1) that there is value in applying a 'social lens' to help understand the way communities of practice use technology and that an understanding of the affordances of the technologies is key to using them to promote teaching and learning.

As facilitators of learning through online blogs and communities in the field of teacher education, we recommend supporting participants to develop explicit understanding of how their personal pedagogies evolve through the creation and sharing of multimodal content and how the process of transferring their learning to practice occurs in reflexive cycles across physical and digital habitats.

\section{References:}

Alley, S. Jackson, S. Shakya, Y. (2015). Reflexivity: A methodological tool in the knowledge translation process. Health Promotion Practice, 16.3, 426-431.

Anderson, T. \& Dron, J. (2011). Three generations of distance education pedagogy. The International Review of Research in Open and Distance Learning, 12.3, 81-97. Retrieved from http://www.irrodl.org/index.php/irrodl/article/view/890/1663

Banks, M. (2007). Using visual data in qualitative research. London: Sage.

Brown, S. (2004). Assessment for learning. Learning and Teaching in Higher Education. 1.

Churchill, D. (2009). Educational applications of Web 2.0: Using blogs to support teaching and learning. British Journal of Educational Technology, 40.1, 179-183.

Cowan, J. (2006). On becoming an Innovative University teacher: Reflection in Action. ( $2^{\text {nd }} e d$.). Berkshire: Open University Press.

Deng, L., and Yuen, A. H. (2011). Towards a framework for educational affordances of blogs. Computers and Education, 56(2), 441-451.

Denning, P.J., 2004. The social life of innovation. Communications of the ACM, 47(4), 15-19.

DfE. (2013). National Curriculum in England. Department for Education. Retrieved from: https://www.gov.uk/government/publications/nationalcurriculum-in-england-primary-curriculum

Donohue, C. and Fox, C. (2012). Lessons Learned, Innovative Practices, and Emerging Trends: Technology for Teacher Education and Professional Development. Exchange: The Early Childhood Leaders' Magazine Since 1978, 204, 74-80.

Downes, S. (2010). What is democracy in education? [Web blog post]. Retrieved from http://halfanhour.blogspot.com/2010/10/what-is-democracy-ineducation.html 
Farmer, B., Yue, A., and Brooks, C. (2008). Using blogging for higher order learning in large cohort university teaching: A case study. Australasian Journal of Educational Technology, 24(2), 123-136.

Gruska, K. (2005). Artists as reflective self-learners and cultural communicators: an exploration of the qualitative aesthetic dimension of knowing self through reflective practice in art making. Reflective practice, 6.3, 353-366.

Gulbrandsen M. \& Aanstad S. (2014) Is innovation a useful concept for arts and humanities research? In, Fagerberg J, Mowery D., Nelson RR (eds) The Oxford handbook of innovation. Oxford University Press, Oxford.

Gunawardena, C. Hermans, M. Sanchez, D. Richmond, C. Bohley, M. \& Tuttle, R. (2009). A theoretical framework for building online communities of practice with social networking tools. Educational Media International, 46.1, 3-16.

Hammond, M. (1998). Learning through online discussion. Journal of Information Technology for Teacher Education,7.3, 331-346.

Heaton, R. (2014). Moving mindsets: Re-conceptualising the place of visual culture as multi-sensory culture in primary art education. Canadian Review of Art Education, 41.1, 77-96.

Hung, D. (2002). Situated cognition and problem-based learning: implications for learning and instruction with technology. Journal of Interactive Learning Research, 13.4, 393-415.

Johnson, C. M. (2001). A survey of current research on online Communities of Practice. The Internet and Higher Education, 4.1, 45-60.

Kolb, D. (1984). Experimental Learning: Experience as the source of learning and development. London: Englewood Cliffs.

Liedka, J. (1999). Linking competitive advantage with Communities of Practice. Journal of Management Inquiry, 8.1, 5-16.

Luckin, R. Clark, W. Garnett, F. Whitworth, A. Akass, J. Cook, J., ... \& Robertson, J. (2010). Learner-Generated Contexts: A Framework to Support the Effective. Web 2.0-Based E-Learning: Applying Social Informatics for Tertiary Teaching: Applying Social Informatics for Tertiary Teaching, 70.

Markham, T. (2003). Project based learning handbook: A guide to standardsfocused project based learning for middle and high school teachers. California: Buck Institute for Education.

Mason, R. \& Rennie, F. (2008). Social networking as an educational tool. Elearning and social networking handbook: Resources for higher education, 1-24. 
McNiff, S. (2011). Artistic expressions as primary modes of inquiry. British Journal of Guidance and Counselling, 39.5, 385-396.

Ovens, P., 2003. A patchwork text approach to assessment in teacher education. Teaching in Higher Education, 8(4), pp.545-562.

Ozturk, H. \& Ozcinar, H. (2013). Learning in multiple communities from the perspective of knowledge capital. The International Review of Research in Open and Distributed Learning, 14.1, 204-22

Palloff, R. \& Pratt, K. (1999). Building learning communities in cyberspace: effective strategies for the online classroom. San Francisco: Jossey-Bass.

Pink, S. (2003). Interdisciplinary agendas in visual research: re-situating visual anthropology. Visual Studies, 18.3, 179-192.

Pink,S. (2012). Advances in visual methodology. London: SAGE.

Reedy, G. (2008). PowerPoint, interactive whiteboards, and the visual culture of technology in schools. Technology, Pedagogy and Education, 17.2, 143162.

Reupert, A. and Dalgarno, B. (2011). Using online blogs to develop student teachers' behaviour management approaches. Australian Journal of Teacher Education, 36.5, 5.

Richardson, W. (2010). Blogs, wikis, podcasts and other powerful web tools for classrooms. Thousand Oaks, CA: Corwin.

Rohaan, E. Taconis, R. and Jochems, W. (2010). Reviewing the Relations between Teachers' Knowledge and Pupils' Attitude in the Field of Primary Technology Education. International Journal of Technology and Design Education, 20 (1) 15-26.

Rose, G. (2012). Visual Methodologies. ( $3^{\text {rd }}$ ed). London: SAGE.

Saadatmand, M. \& Kumpulainen, K. (2014). Participants' perceptions of learning and networking in connectivist MOOCs. MERLOT Journal of Online Learning and Teaching, 10.1, 16-30.

Schon, D. (1983) The Reflective Practitioner. New York: Basic Books.

Scott, D. and Morrison, M. (2006). Key ideas in educational research. London: Continuum.

Sharples, M. Adams, A. Ferguson, R. Gaved, M. McAndrew, P. Rienties, B. \& Whitelock, D. (2014). Innovating Pedagogy. Open University Innovation Report, 3, 1-35.

Siemens, G. (2005). Connectivism: A learning theory for the digital age. International Journal of Instructional Technology and Distance Learning, 2.1, 3-10. Retrieved from http://www.itdl.org/Journal/Jan_05/article01.htm

Silvermn, D. (2013) Doing Qualitative Research: A Practical Handbook. ( ${ }^{\text {st }}$ and $4^{\text {th }}$ ed.). London: SAGE. Spry, T. (2001). Performing auto-ethnography: 
An embodied methodological praxis. Qualitative Inquiry, 7, 706-732.

Retrieved from:

http://qix.sagepub.com/cgi/content/abstract/7/6/706Sullivan, G. (2005). Art practice as research. ( $1^{\text {st }}$ and $2^{\text {nd }}$ eds.). London: SAGE

Stobaugh, R. and Tassell, J. (2011). Analyzing the Degree of Technology Use Occuring in Pre-Service Teacher Education. Educational Assessment, Evaluation and Accountability, 23 (2) 143-157.

Wenger, E. (2011). Communities of Practice: A brief introduction. Retrieved from: https://scholarsbank.uoregon.edu/xmlui/handle/1794/11736

Wenger, E. White, N. \& Smith, J. D. (2009). Digital habitats: Stewarding technology for communities. Portland: CPsquare.

Wheeler, S. (2010). Open content, open learning 2.0: Using wikis and blogs in Higher Education. Changing cultures in higher education, 103-114.

Wick, C. (2000). Knowledge management and leadership opportunities for technical communicators. Technical Communication, 47.4, 515-529.

Winters, R. (2003). Contextualizing the Patchwork Text: Addressing Problems of Coursework Assessment in Higher Education. IETI, 40 (2), 112-122.

Williams, J. B. and Jacobs, J. (2004). Exploring the use of blogs as learning spaces in the higher education sector. Australasian Journal of Educational Technology, 20.2, 232-247.

Yang, S. H. (2009). Using blogs to enhance critical reflection and community of practice. Educational Technology and Society, 12.2, 11-21 